\title{
Faktor Yang Memengaruhi Perilaku Perawat Terhadap Penerapan Sistem Manajemen Kesehatan Dan Keselamatan Kerja Di RSUD Langsa
}

\author{
Rosmawar*, Asriwati, Achmad Rifai \\ S2 IImu Kesehatan Masyarakat, Institut Kesehatan Helvetia Medan \\ *Email : rose03ff76@gmail.com
}

\begin{abstract}
ABSTRAK
Besarnya risiko dari berbagai potensi bahaya yang ada di Rumah Sakit Umum Daerah Langsa diperlukan upaya untuk mengendalikan, meminimalir terjadinya kecelakaan kerja, salah satunya adalah dengan menerapkan SMK3 Penelitian ini bertujuan untuk menganalisis faktor yang memengaruhi perawat terhadap penerapan SMK3. Desain penelitian menggunakan survei analitik dengan rancangancross sectional. Sampel dalam penelitian ini sebanyak 82 orang yang diperoleh denan simple random sampling. Data penelitian yaitu data primer, data sekunder dan tersier. Data penelitian dianalisis secara univariat, bivariat dan multivariat dengan menggunakan uji regresi logistic. Hasil penelitian menunjukkan bahwa ada pengaruh pengetahuan terhadap penerapan SMK3 $(p=0,002)$, ada pengaruh sikap terhadap penerapan SMK3 $(p=0,010)$, ada pengaruh tindakan terhadap penerapan SMK3 $(p=0,005)$, ada pengaruh persepsi terhadap penerapan SMK3 $(p=0,028)$, ada pengaruh sarana prasarana terhadap penerapan SMK3 $(p=0,000)$, ada pengaruh dukungan pimpinanterhadap penerapan SMK3 $(p=0,021)$. Kesimpulan bahwa bahwa ada pengaruh pengetahuan, sikap, tindakan, persepsi, sarana prasarana dan dukungan pimpinan terhadap penerapan SMK3 di RSUD Langsa dan variabel yang paling dominan berpengaruh adalah variabel tindakan. Saran pada penelitian ini yaitu agar pihak Rumah sakit dapat mengadopsi inovasi teknologi berbasis android sehingga perawat dapat mengakses penerapan K3RS secara mandiri.
\end{abstract}

Kata Kunci $\quad$ : Pengetahuan Sikap dan Tindakan, Persepsi, Sarana Prasarana, Dukungan Pimpinan

\begin{abstract}
The amount of risk from various potential hazards in the hospital so that efforts are needed to control and minimize the occurrence of work accidents, one of which is by implementing SMK3. This study aims to analyze the factors that influence nurses on the implementation of the occupational health and safety management system at Langsa City Hospital. The research design used an analytic survey with a cross sectional design. The sample of this study was 82 people used was simple random sampling. Data collection methods are primary data, secondary data and tertiary data. The research data were analyzed by univariate, bivariate and multivariate using logistic regression tests. The results showed that there was an effect of knowledge on the application of SMK3 $(p=0.002)$, there was an effect of attitude on the application of SMK3 $(p=0.010)$, there was an effect of action on the application of SMK3 $(p=0.005)$, there was an effect of perception on the application of SMK3 $(p=0.028)$ ), there is an effect of infrastructure on the implementation of SMK3 $(p=0.000)$, there is an effect of leadership support on the implementation of SMK3 $(p=0.021)$ and the most dominant variable is the action variable. Based on the research results, it can be concluded that there is an influence of knowledge, attitudes, actions, perceptions, infrastructure and leadership support on the implementation of SMK3 at Langsa Hospital. The suggestion in this research is that the hospital can adopt rifaskes innovation that can help the best health services for nurses.
\end{abstract}

Keywords $\quad$ : Knowledge Attitudes and Actions, Perception, Infrastructure, Leadership Support 


\section{PENDAHULUAN}

Kecelakaan kerja merupakan salah satu kejadian yang sering terjadi di dunia kerja. Kecelakaan kerja menimbulkan korban jiwa maupun kerugian materi bagi pekerja. Secara global, International Labour Organization (ILO) tahun 2019 memperkirakan sekitar 337 juta kecelakaan kerja terjadi tiap tahunnya yang mengakibatkan sekitar 2,3 juta pekerja kehilangan nyawa, satu pekerja di dunia meninggal setiap 15 detik karena kecelakaan kerja dan 160 pekerja mengalami sakit akibat kerja. ${ }^{1}$

Di Indonesia tahun 2018 rata-rata terdapat 99.000 kasus kecelakaan kerja, $70 \%$ berakibat fatal, kematian dan cacat seumur hidup. Dimana 9 pekerja meninggal setiap hari, yang mengakibatkan kerugian nasional mencapai $\mathrm{Rp}$ 50 triliun.Tahun 2018 Kepmenkes, laporan pelaksanaan kesehatan kerja di Provinsi di Indonesia tahun 2017, jumlah kasus penyakit umum pada pekerja ada sekitar 2.998.766 kasus, dan jumlah kasus penyakit yang berkaitan dengan pekerjaan berjumlah 428.844 kasus. $^{2}$ Sedangkan angka Kecelakaan Kerja dan Penyakit Akibat Kerja yang ada di Rumah Sakit di Indonesia berdasarkanpenelitian dr. Joseph tahun 2005-2007 mencatat bahwa angka Kecelakaan Akibat Kerja (KAK) karena tertusuk jarum suntik mencapai 38-73\%dari total petugas kesehatan. ${ }^{3}$

Salah satu Sumber Daya Manusia di Rumah Sakit yang sering mengalami kecelakaan kerja adalah perawat. Perawat merupakan petugas kesehatan dengan presentasi terbesar dan memegang peran penting dalam pemberian pelayanan kesehatan. ${ }^{4}$ ILO 2017 mencatat, dari 39,47 juta petugas kesehatan di seluruh dunia, $66,7 \%$-nya adalah perawat. Di Indonesia, perawat juga merupakan bagian terbesar dari tenaga kesehatan yang bertugas di rumah sakit yaitu sekitar 47,08\% dan paling banyak berinteraksi dengan pasien. ${ }^{5}$

Kesehatan dan Keselamatan perawat di rumah sakit diperngaruhi oleh Sistem Manajemen Keselamatan dan Kesehatan Kerja atau yang sering disebut SMK3 yang ada di rumah sakit itu. SMK3 adalah sistem manajemen yang berfungsi untuk mengatur keselamatan dan kesehatan kerja di suatu industri atau gedung. Penerapan SMK3 harus meliputi 12 unsur yang tercantum pada pasal 16 ayat 3 PP No. 50 Tahun 2012. ${ }^{6}$ Agar 12 unsur itu dapat di terapkan, sebaiknya perlu adanya komitmen dari perawat. Perawat dituntut untuk menerapkan SMK3 dengan harapan dapat meminimalisir angka kecelakaan kerja.

Dalam menerapkan SMK3, perawat dipengaruhi oleh berbagai factor perilaku dari perawat itu sendiri dan lingkungannya. Hal ini sejalan dengan teori L.W green bahwa perilaku kesehatan dipengaruhi oleh faktor predisposisi, faktor pemungkin, dan faktor penguat. Kecelakaan kerja yang disebabkan oleh berbagai faktor dalam pekerjaan bisa dihindarkan, apabila perawat dan pimpinan rumah sakit ada kemauan baik untuk mencegahnya. ${ }^{7}$

Salah satu Rumah sakit yang menerapkan SMK3 adalah Rumah Sakit Umum Daerah dr. Zainoel Abidin Banda Aceh. Berdasarkan data sekunder Rumah sakit tersebut diketahui bahwa pada tahun 2015 di Rumah Sakit Umum Daerah dr. Zainoel Abidin Banda Aceh telah terjadi 19 kasus kecelakaan kerja. Rincian kasus yang didapatkan dimana 18 kasus terjadi pada perawat yaitu 13 orang perawat tertusuk jarum, 2 orang terpapar cairan tubuh, 1 orang terpapar cairan B3 (obat kemoterapi), dan 2 orang terpeleset sedangkan 1 kasus lainnya terjadi pada petugas pemeliharaan sarana yang terluka akibat terlepasnya penutup tabung oksigen. Ketua Komite Kesehatan dan Keselamatan Kerja Rumah Sakit (K3RS) juga meyakini bahwa masih banyak kasus-kasus kecelakaan kerja lainnya yang tidak dilaporkan kepada pihak rumah sakit.

Berdasarkan hasil survei awal dilakukan oleh peneliti terhadap 10 orang perawat di RSUD Kota Langa diketahui bahwa sebanyak 4 oranng perawat yang menyatakan kurang mengetahui adanya SMK3 karena masih baru bekerja selama beberapa bulan, ada sebanyak 7 orang yang menyatakan bahwa sering mengalami kecelakaan kerja karena memiliki sikap negative karena sering mengabaikan SMK3 dan sering tidak menggunakan APD pada saat bekerja,. Selain itu perawat juga menyatakan kurangnya sarana prasarana yang menunjang keselamatan kerja dan kurangnya perhatian pimpinan terhadap Maanajemen kesehatan dan keselamaatan kerja.

SMK3 yang dibuat pada rumah sakit mencakup perencanaan, pengorganisasian, pelaksanaan dan evaluasi. Perencanaan yang ada di RSUD Kota Langsa masih tergolong kurang efektif dalam penerapan SMK3 seperti tidak adanya perencanaan kegiatan asuhan keperawatan setiap harinya, menyusun kebutuhan yang diperlukan perawat dan membuat perencanaan tentang tugas-tugas yang dijalankan perawat sesuai dengan kemampuannya. Selanjutnya fungsi pelaksanaan SMK3 masih juga belum terstruktur dengan baik seperti masih ada 
perawat yang tidak menjalankan SMK3 sesuai dengan ketentuan yang telah dibuat oleh rumah sakit. Minimnya akan pengetahuan dan kesadaran perawat tentang K3 merupakan dampak terbesar kegagalan pelaksanakan SMK3. Berdasarkan uraian pada latar belakang di atas, maka tujuan penelitan ini adalah untuk menganalisis faktor yang memengaruhi perilaku perawat terhadap penerapan sistem manajemen keselamatan dan kesehatan kerja di RSUD Kota Langsa".

\section{METODE PENELITIAN}

Jenis penelitian ini adalah penelitian survei analitik dengan rancangan cross sectional. Penelitian ini dilakukan di RSUD Kota Langsa pada bulan Mei-Agustus tahun 2020. Populasi dalam penelitian ini adalah seluruh tenaga perawat di RSUD Kota Langsa berdasarkan data bulan Maret 2020 sebanyak 445 orang. Sampel yang dilibatkan pada penelitian ini adalah sebanyak 82 perawat. Pengambilan sampel menggunakan teknik simple random sampling. Data dianalisi dengan menggunakan uji ChiSquare dan Regresi Logistik

\section{HASIL}

Tabel 1 Distribusi Responden di RSUD Langsa

Umur
21-25 tahun
26-30 tahun
31-35 tahun
36-40 Tahun
41-45 Tahun
46-50 Tahun
Jenis Kelamin
Laki-Laki
Perempuan
Pendidikan
S2
S1
Ners
D3 Keperawatan
Lama Bekerja
$\geq 30$ tahun
< 3 tahun
Jumlah

Berdasarkan tabel 1. diketahui bahwa dari 82 responden, sebagian besar responden memiliki umur 26-30 tahun sebanyak 22 responden $(26,8 \%)$ dan sebagian besar berjenis kelamin perempuan sebanyak 47 responden $(57,3 \%)$.

\begin{tabular}{cc}
$\mathbf{n}$ & $\%$ \\
8 & \\
22 & 9,8 \\
19 & 26,8 \\
14 & 23,2 \\
13 & 17,1 \\
6 & 15,9 \\
$\mathrm{n}$ & 7,3 \\
35 & $\%$ \\
47 & 42,7 \\
$\mathrm{n}$ & 57,3 \\
2 & $\%$ \\
27 & 2,4 \\
18 & 32,9 \\
35 & 22,0 \\
$\mathrm{n}$ & 42,7 \\
50 & $\%$ \\
32 & 61,0 \\
$\mathbf{8 2}$ & 39,0 \\
\hline & 100
\end{tabular}

Pada kategori pendidikan diketahui sebagian besar responden memiliki pendidikan D3 Keperawatan sebanyak 35 responden $(42,7 \%)$, sedangkan pada kategori lama kerja, sebagian besar responden memiliki lama kerja $\geq 3$ tahun sebanyak 50 responden $(61,0 \%)$.

Tabel 2. Faktor yang memengaruhi penerapan SMK3 di RSUD Langsa

\begin{tabular}{|c|c|c|c|c|c|c|c|}
\hline \multirow[t]{3}{*}{ Pengetahuan } & \multicolumn{6}{|c|}{ Penerapan SMK3 } & \multirow[t]{2}{*}{$P$ value } \\
\hline & \multicolumn{2}{|c|}{ Diterapkan } & \multicolumn{2}{|c|}{ Kurang diterapkar } & \multicolumn{2}{|c|}{ total } & \\
\hline & $n$ & $\%$ & $\mathrm{n}$ & $\%$ & $\mathrm{n}$ & $\%$ & 0,002 \\
\hline \multirow{2}{*}{$\begin{array}{l}\text { Baik } \\
\text { Kurang Baik }\end{array}$} & 33 & 40,2 & 7 & 8,5 & 40 & 48,8 & \\
\hline & 6 & 7,3 & 36 & 43,9 & 42 & 51,2 & \\
\hline Total & 39 & 47,6 & 43 & 52,4 & 82 & 100 & \\
\hline \multirow[t]{3}{*}{ Sikap } & \multirow{2}{*}{\multicolumn{2}{|c|}{ Diterapkan }} & Pener & SMK & & & $P$ value \\
\hline & & & Kuran & erapk & \multicolumn{2}{|c|}{ total } & \\
\hline & $\mathrm{n}$ & $\%$ & $\mathrm{n}$ & $\%$ & $\mathrm{n}$ & $\%$ & 0,010 \\
\hline
\end{tabular}






Berdasarkan tabel 2 diketahui bahwa dari 82 responden yang diteliti ada sebanyak 40 responden $(48,8 \%)$ yang berpengetahuan baik, sebanyak 33 responden $(40,2 \%)$ menerapkan SMK3 dan sebanyak 7 responden (8,5\%) kurang menerapkan SMK3. Berdasarkan hasil uji statistik diperoleh pvalue $0,002<0,05$ sehingga ada pengaruh pengetahuan terhadap penerapan SMK3 di RSUD Langsa.

Dari 82 responden yang diteliti ada sebanyak 38 responden $(46,3 \%)$ yang bersikap positif, sebanyak 31 responden $(37,8 \%)$ menerapkan SMK3 dan sebanyak 7 responden $(8,5 \%)$ yang kurang menerapkan SMK3. Berdasarkan hasil uji statistik diperoleh pvalue $0,010<0,05$ sehingga ada pengaruh sikap terhadap penerapan SMK3 di RSUD Langsa.

Dari 82 responden yang ada sebanyak 55 responden $(67,1 \%)$ memiliki tindakan yang baik, sebanyak 26 responden (31,7\%) menerapkan SMK3 dan sebanyak 29 responden $(35,4 \%)$ yang kurang menerapkan SMK3. Berdasarkan hasil uji statistik diperoleh pvalue 0,005 $<0,05$ sehingga ada pengaruh tindakan terhadap penerapan SMK3 di RSUD Langsa.

Dari 82 responden yang diteliti ada sebanyak 44 responden $(53,7 \%)$ yang memiliki persepsi positif, sebanyak 23 responden $(28,0 \%)$ menerapkan SMK3 dan sebanyak 21 responden $(25,6 \%)$ kurang menerapkan SMK3. Berdasarkan hasil uji statistik diperoleh pvalue $0,028<0,05$. sehingga ada pengaruh persepsi terhadap penerapan SMK3 di RSUD Langsa.

Dari 82 responden yang diteliti ada sebanyak 39 responden $(47,6 \%)$ yang menyatakan bahwa sarana prasarana dalam kategori memadai, sebanyak 33 responden $(40,2 \%)$ menerapkan SMK3 dan sebanyak 6 responden $(7,3 \%)$ yang kurang menerapkan SMK3. Berdasarkan hasil uji statistik diperoleh pvalue $0,000<0,05$. sehingga ada pengaruh sarana prasarana terhadap penerapan SMK3 di RSUD Langsa.

Dari 82 responden yang diteliti ada sebanyak 38 responden (46,3\%) yang menyatakan bahwa dukungan pimpinan dalam kategori mendukung, sebanyak 21 responden (25,6\%) menerapkan SMK3 dan sebanyak 17 responden (20,7\%) yang kurang menerapkan SMK3. Berdasarkan hasil uji statistik diperoleh pvalue 0,021 $<0,05$ sehingga ada pengaruh dukungan pimpinan terhadap penerapan SMK3 di RSUD Langsa. 


\section{PEMBAHASAN}

\section{Pengaruh Pengetahuan dengan Penerapan SMK3 di RSUD Langsa}

Pengetahuan merupakan tingkat paling dasar manumur memahami semua materi yang melalui sistem penginderaan. Pengetahuan yang baik harus dibarengi dengan tindakan yang baik pula. Oleh sebab itu pelatihan dapat digunakan sebagai strategi yang dikhususkan untuk perubahan perilaku perawat tersebut, dengan cara mengarah pada diperolehnya keterampilan. Namun, selain untuk mengembangkan keterampilan, pelatihan juga memberikan perubahan pengetahuan seseorang mengenai penerapan. Selain itu pelatihan yang diberikan kepada perawat juga juga dapat berfungsi untuk mempersiapkan perawat tersebut guna melaksanakan pekerjaan mereka. ${ }^{9}$ Dengan pelatihan Keselamatan dan Kesehatan Kerja (K3) sebagai cues to action (pendorong untuk bertindak), diharapkan seorang perawat mendapatkan pengetahuan dan informasi baru. Hal tersebut dapat memengaruhi seseorang dalam mendapatkan pengertian yang benar tentang kerentanan, kegawatan, dan kerugian dari tindakan pencegahan dan pengendalian yang dilakukan. Pemberian pelatihan juga dimaksudkan untuk meningkatkan kesadaran (awareness) perawat mengenai tindakan K3.

Pengetahuan yang kurang dari petugas dikarenakan perawat merasa sudah memahami penerapan SMK3 di rumah sakit sehingga mereka tidak mau mengikuti pelatihan yang diadakan secara lengkap dan tidak adanya teguran yang diberikan oleh atasan bagi yang melanggar aturan sehingga perawat banyak yang lalai melaksanakan penerapan SMK3 di rumah sakit, padahal pengetahuan tentang keselamatan sangat penting dalam rangka menciptakan lingkungan kerja yang aman dan meningkatkan kesadaran akan keselamatan. Banyak petugas yang hanya sebatas mengetahui dan mengingat namun mereka belum memahami secara jelas maksud dan tujuan dari pelaksanaan SMK3 dan menyebabkan pelaksanaan SMK3 di lingkungan rumah sakit tidak efektif dan masih banyak petugas yang tidak melaksanakannya. Pengetahuan yang kurang dari perawat tentang penerapan SMK3 menimbulkan tindakan yang kurang baik dalam pelaksanaan K3 di lingkungan rumah sakit. Hal ini menunjukkan bahwa pengetahuan harus dimiliki dengan baik sehingga akan menimbulkan tindakan pelaksanaan SMK3 yang baik juga. Sejalan dengan penelitian yang dilakukan oleh Setyowati tahun 2018 dengan judul Hubungan Pengetahuan, Sikap, Pelatihan, Pimpinan an dengan Persepsi tentang Penerapan SMK3, menunjukkan bahwa pengetahuan tentang SMK3 merupakan variabel yang berhubungan dengan persepsi responden tentang penerapan SMK3 yaitu dengan nilai $p=0.029 .^{10}$

Menurut asumsi peneliti menunjukkan bahwa pengetahuan dengan penerapan SMK3 memiliki hubungan yang signifikan. Hal ini membuktikan bahwa semakin baik pengetahuan responden maka akan semakin baik pula responden melakukan penerapan SMK3, begitu sebaliknya apabila pengetahuan responden tidak baik maka penerapan SMK3 juga akan tidak baik. Dalam hal ini banyak sebagian besar responden memiliki pengetahuan yang baik dikarenakan informasi yang diberikan kurang baik, tidak adanya arahan dalam melakukan penerapan SMK3 dari pihak rumah sakit, kurangnya pimpinan an yang dilakukan dalam memantau pelaksanaan SMK3 sehingga responden tidak paham dan kurang mengerti bagaimana melakukan penerapan SMK3 secara baik dan benar.

\section{Pengaruh Sikap dengan Penerapan SMK3 di RSUD Langsa}

Sikap perawat dalam menerapkan SMK3 di RSUD Langsamerupakan proses sosialisasi dimana perawat bereaksi sesuai dengan rangsangan yang diterimanya dari pimpinan maupun dari lingkungan tempat ia bekerja. Sebelum perawat mendapat informasi atau obyek itu, tidak mungkin terbentuk sikap. Suatu sikap dapat terbentuk pada individu karena adanya keyakinan akan akibat suatu perilaku. Sikap yang terbentuk ini dapat bersifat positif maupun negatif tergantung pada besarnya pengetahuan. Jadi semakin tinggi tingkat pengetahuan seseorang akan memengaruhi terbentuknya sikap dan selanjutnya diwujudkan dalam bentuk tindakan. ${ }^{10}$

Hasil jawaban kuesioner menunjukkan bahwa ada sebanyak 21 orang perawat yang menyatakan bahwa kebijakan safety penting sebagai pencegahan kecelakaan kerja. Pemahaman manajemen tentang pentingnya keselamatan kerja merupakan dasar dari setiap kebijakan yang harus dibuat dalam Manajemen Keselamatan Kerja. Doktrin dasar yang harus dipahami adalah bahwa pencegahan atau pemeliharaan keselamatan kerja adalah lebih baik dari penanggulangan setelah terjadi keselamatan kerja. 
Menurut asumsi peneliti sikap yang negatif terhadap penerapan SMK3 rumah sakit mempunyai peluang yang besar dapat menyebabkan kecelakaan kerja dibandingankan dengan sikap yang positif. Hal ini juga terlihat bahwa sebagian besar perawat masih memiliki sikap yang negatif dalam menanggapi SMK3 yang ada di rumah sakit. Bagi setiap petugas rumah sakit agar mempunyai sikap yang baik terhadap penerapan SMK3 rumah sakit agar kecelakaan akibat kerja dan penyakit akibat kerja dapat dikurangi. Oleh karena itu direkomendasikan kepada perawat dan semua petugas di rumah sakit untuk bersikap positif terhadap prosedur pelaksanaan keselamatan dan kesehatan kerja dalam bentuk mendukung/menyetujui segala program K3 khususnya untuk pencegahan kecelakaan kerja maka diusahakan adanya sikap yang pro aktif untuk mengaplikasikan ilmu baru tentang pelaksanaan keselamatan dan kesehatan kerja. Semakin pro aktif mengaplikasikan ilmu baru maka akan semakin bersikap positif tentang pelaksanaan SMK3 sehingga akan mengurangi kejadian kecelakaan kerja.

\section{Pengaruh Tindakan dengan Penerapan SMK3 di RSUD Langsa}

Tindakan Kesehatan dan keselamatan kerja di rumah sakit adalah segala bentuk upaya terpadu seluruh pekerja rumah sakit, pasien, pengunjung atau pengantar orang sakit untuk menciptakan lingkungan kerja dan tempat kerja rumah sakit yang sehat, aman, dan nyaman baik bagi pekerja rumah sakit, pasien, pengunjung maupun masyarakatyang terdapat dalam lingkungan rumah sakit. Salah satu faktor kesehatan dan keselamatan kerja yaitu tindakan sangat berpengaruh pada kesehatan keselamatan kerja bagi perawat di rumah sakit.

Hasil jawaban kuesioner menunjukkan bahwa ada sebanyak 17 orang perawat yang bekerja sesuasi dengan SPO yang ditetapkan, misalnya menggunakan masker, sarung tangan pada saat sedang menangani pasien, ada sebanyak 34 orang perawat yang menyatakan sangat setuju bahwa pada saat berada ditempat kerja perawat selalu memperhatikan safety sign (poster dan rambu) termasuk jalur evakuasi ketika bekerja. Selain itu sebanyak 16 orang perawat yang menyatakan sangat setuju bahwa ketika berada dalam lingkungan rumah sakit selalu mengutamakan keselamatan dalam bekerja. Sebanyak 21 orang perawat yang menyatakan sangat setuju bahwa ketika berada dalam lingkungan rumah sakit selalu memanfaatkan fasilitas pelayanan kesehatan yang disediakan bagi petugas rumah sakit, 15 orang perawat yang menyatakan menggunakan APD (jika diperlukan) saat bekerja dan melaporkan kejadian K3 sesuai alur/prosedur yang ditetapkan RS dan sebanyak 23 orang perawat ikut dalam setiap kegiatan pelatihan/sosialisasi terkait penerapan SMK3

Menurut asumsi peneliti, peranan perawat pada program Kesehatan dan Keselamatan Kerja bisa dikatakan sangat bermakna,mengingat tugas fungsional perawat dalam K3 begitu luas. Bisa dikatakan bahwa fokus utamaperawatan kesehatan kerja adalah kesehatan dan keselamatan kerja bagi tenaga kerja denganpenekanan pada pencegahan terjadinya penyakit dan cidera. Hal ini senada dengan tujuan K3. Hanya saja perawatan kesehatan kerja belum seperti yang diharapkan. Peranan profesi dalam mengembangkan tingkat profesionalisme belum terlihat bermakna. Untuk menjaga mutu profesionalisme, sudah saatnya kita semua memikirkan upaya yang perlu dilakukan. Salah satunya diharapkan organisasi profesi meningkatkan peranannya dalam membina dan memantau anggotanya, serta menerus aktif dalam meningkatkan kemampuan dan keterampilan anggotanya.

\section{Pengaruh Persepsi dengan Penerapan SMK3 di RSUD Langsa}

Lingkungan melalui alat indera.Akan tetapi ada perbedaan persepsiantara individu satu dan lainnya.Sehingga, dengan adanya perbedaanpersepsi ini perilaku yang ditampilkan oleh tiap perawat akanberbeda.

Menurut asumsi peneliti,persepsi perawat sebagai proses mengetahui atau mengenali objek dan kejadian objektif dengan bantuan indera. Proses perseptual ini dimulai dengan perhatian, yaitu merupakan proses pengamatan selektif.Dalam proses persepsi, terdapat tiga komponen utama, yaitu: seleksi, yaitu penyampaian oleh indera terhadap rangsangan dari luar, intensitas dan jenisnya dapat banyak atau sedikit; b) Interpretasi, yaitu proses mengorganisasikan informasi sehingga mempunyai arti bagi seseorang; c) Pembulatan, yaitu penarikan kesimpulan dan tanggapan terhadap informasi yang diterima.Maka dari penjelasan mengenai aspek persepsi di atas dapat diambil kesimpulan bahwa aspek persepsi terdiri dari seleksi yakni penyampaian oleh indera, interpretasi yang merupakan proses pengorganisasian informasi dan pembulatan 
adalah bagaimana cara individu membuat kesimpulan. ${ }^{11}$

\section{Pengaruh Sarana Prasarana dengan Penerapan SMK3 di RSUD Langsa}

Alat kerja dan bahan merupakan suatu hal yang pokok dibutuhkan oleh rumah sakit untuk memproduksi barang. Dalam memproduksi barang alat-alat kerja sangatlah vital yang digunakan oleh para pekerja dalam melakukan kegiatan proses produksi dan di samping itu adalah bahan-bahan utama yang akan dijadikan barang. Pelaksanaan sistem manajemen keselamatan dan kesehatan kerja di rumah sakit selalu membutuhkan peralatan-peralatan yang menunjang semua kegiatan. Pihak Rumah sakit sudah menyediakan peralatan-peralatan K3 di setiap unit kerja untuk mengurangi risiko kecelakaan kerja yang mungkin terjadi pada pekerja rumah sakit

Menurut asumsi peneliti faktor-faktor yangmempengaruhiKeselamatan danKesehatan Kerja (K3), meliputipersepsi tentang sarana dan prasarana seperti:Tata RuangKerja, pakaian kerja, alatPelindung Diri (APD), meliputi pelindung mata, sepatupengaman, sarung tangan, danpelindung hidung (masker), lingkungan kerja yang meliputi udara, suara dan pencahayaan.SOP sangat dibutuhkan untuk membantu kinerja para petugas karena setiap tindakan ada prosedurnya sehingga dapat mengurangi masalah-masalah atau kekeliruan yang bisa terjadi. RSUD Langsa sudah menyiapkan SOP di setiap unit kerja di rumah sakit, meskipun SOP yang menjurus pada pelaksanaan K3 belum ada. SOP ini wajib di patuhi oleh semua perawat.

\section{Pengaruh Dukungan Pimpinan Terhadap Penerapan SMK3di RSUD Langsa}

Kesejahteraan pekerja dapat dibedakan menurut jenisnya, antara lain jenis-jenis kesejahteraan yang diberikan adalah finansial dan non finansial yang bersifat ekonomis, serta pemberian fasilitas dan pelayanan. Pemberian kesejahteraan pekerja peru direncanakan dengan matang dan diprogam dengan baik supaya bermanfaat dalam mendukung tujuan rumah sakit, pekerja dan masyarakat. Progam kesejahteraan harus diinformasikan secara terbuka dan jelas, waktu pemberiannya tepat dan sesuai dengan kebutuhan pekerja Hasil jawaban kuesioner menunjukkan bahwa sebanyak 13 orang perawat yang menyatakan bahwa pimpinan memberikan arahan dalam pelaksanaan K3 di masing-masing unit/bagian.
Seseorang yang bekerja di Bagian K3 bertugas menjamin dan melindungi keselamatan serta kesehatan tenaga kerja melalui berbagai upaya keamanan pekerja. Beberapa hal yang mungkin bisa dilakukan adalah pencegahan kecelakaan seperti kebakaran, cedera ataupun hal-hal lain yang mungkin bisa membahayakan. Bagian K3 bertanggung jawab memberikan pencegahan, arahan dan pertolongan jika terjadi hal yang terjadi pada karyawan.

Peninjauan dan peningkatan kinerja SMK3 dilakukan untuk menjamin kesesuaian dan keefektifan pencapaian tujuan SMK3 dengan melakukan peninjauan secara berkala dan tinjauan ulang SMK3 dapat mengatasi implikasi K3 terhadap seluruh kegiatan, produk barang termasuk juga dampak terhadap kinerja rumah sakit. Peninjauan ulang SMK3 dilakukan berdasarkan pertimbangan: 1) Perubahan peraturan perundangan; 2) Incident data (cidera, sakit akibat kerja, rekomendasi hasil investigasi kecelakaan kerja); 3) Hasil pengukuran dan pengukuran kinerja, dan laporan kegiatan audit; 4) Masukan yang berasal dari internal dan eksternal rumah sakit ; 5) Perubahan organisasi yang dapat mempengaruhi SMK3; 6) Perubahan kegiatan rumah sakit (penggunaan teknologi, proses dsb) 7) Perkembangan ilmu pengetahuan dan tehnologi;8)Tuntutan pas.

\section{KESIMPULAN DAN SARAN}

Kesimpulan dalam penelitian ini yaitu : Ada pengaruh pengetahuan perawat, sikap perawat, tindakan perawat, persepsi perawat, sarana prasarana, dukungan pimpinan perawat terhadap penerapan Sistem Manajemen Kesehatan dan Keselamatan Kerja di RSUD Langsa dan adapun variabel yang paling dominan berpengaruh terhadap penerapan penerapan Sistem Manajemen Kesehatan dan Keselamatan Kerjadi RSUD Langsa adalah variabel tindakan.

Oleh sebab itu disarankan agar hasil penelitian ini dapat dijadikan sebagai bahan informasi bagi RSUD langsa untuk meningkatkan penerapan SMK3 dengan cara : Semua kecelakaan harus diinvestigasi dan didokumentasikan secara lengkap seperti penyebab dan hasilnya, kerusakan aset/properti, kerusakan/kehilangan peralatan dan luka luka sehingga perawat tidak bermain-main dalam menerapkan SMK3. Perlunya supervisi perawat manager dalam penggunaan APD bagi perawat pelaksana untuk menghindari kejadian kecelakaan kerja di Rumah Sakit. 


\section{DAFTAR PUSTAKA}

1. ILO. Keselamatan dan Kesehatan Kerja Keselamatan dan Kesehatan Sarana untuk Produktivitas. Jakarta: ILO; 2019.

2. Kemenkes RI. Satu Orang Pekerja di Dunia Meninggal Setiap 15 Detik Karena Kecelakaan Kerja.Diakses: 02 Mei 2020. http://www.depkes.go.id/article/print/201 411030005/1-orang-pekeria-di-duniameninggal-setiap-15-detik-karenakecelakaan-kerja.html; 2018

3. The National Safety Council (NSC). Injury Facts 2015 Edition. USA; 2018.

4. International Labour Organization (ILO). Safety and Health at Work. ILO; 2017.

5. Keputusan Menteri Kesehatan Nomor: 1087/MENKES/SK/ VIII/2010

6. Peraturan Pemerintah Republik Indonesia Nomor 50 tahun 2012 tentang Penerapan Sistem Manajemen Keselamatan dan Kesehatan Kerja. 2012.

7. GREEN, Lawrence W. Health program planning. An educational and ecological approach, 2005.

8. RSUD dr. Zainoel Abidin Banda Aceh. Data Komite Kesehatan dan Keselamatan Kerja Rumah Sakit Umum Daerah dr. Zainoel Abidin Banda Aceh. Aceh: RSUD dr. Zainoel Abidin Banda Aceh; 2015.

9. Wijaya R, Paing J. Analisa Faktor-Faktor Yang Mempengaruhi Keselamatan Kerja Perawat Rumah sakit Kontraktor. J Rekayasa dan Manaj Konstr. 2018;6(2):79-88.

10. Yulidar, Girsang E, Napiah A. Analisis Faktor-Faktor yang Mempengaruhi Perilaku Perawat dalam Rangka Penerapan Pasien Safety di Rawat Inap Rumah Sakit Royal Prima Jambi. Sci J. 2018;8(1).
11. Peraturan Menteri Kesehatan Republik Indonesia Nomor 66 Tahun 2016 tentang Keselamatan dan Kesehatan Kerja Rumah Sakit. 2016.

12. Kepmenkes RI. Keputusan Menteri Kesehatan Republik Indonesia Nomor 432/Menkes/SK/IV/2007 tentang Pedoman Manajemen Kesehatan dan Keselamatan Kerja (K3) di Rumah Sakit. 2007.

13. Gillies DA. Manajemen Keperawatan Sebagai Suatu Pendekatan Sistem. Philadelphia: W.B Saunders Company; 1994.

14. Wati N. Analisis Sistem Manajemen Keselamatan dan Kesehatan Kerja di Rumah Sakir Umum Daerah Mukomuko Tahun 2017. Avicenna. 2018;13(3).

15. Wicaksana A. Penyakit Akibat Kerja di Rumah Sakit dan Pencegahannya. Jakarta: Kalbe Farma; 2015.

16. Peraturan Presiden Republik Indonesia. Undang-Undang Nomor 36 tahun 2009 tentang Kesehatan. Jakarta; 2009.

17. Notoatmodjo S. Metodologi Penelitian Kesehatan. Jakarta: Rineka Cipta; 2014.

18. BORSBOOM, Denny; MELLENBERGH, Gideon J.; VAN HEERDEN, Jaap. The concept of validity. Psychological review, 2004, 111.4: 1061.

19. Muhammad I. Panduan Penyusunan Karya Tulis IImiah Bidang Kesehatan. Bandung: Citapustaka Media Perintis; 2015.

20. HANDOKO, Yusri Pamungkas. Studi Penerapan Sistem Manajemen Kesehatan Dan Keselamatan Kerja (K3) Di Pt Skf Indonesia. 2019.

21. HASIBUAN, Malayu SP; HASIBUAN, $H$. Malayu SP. Manajemen sumber daya manumur . Bumi Aksara, 2016. 